\title{
Legal, Institutional and Financial Solutions for the Sustainable Development Strategy of Inland Waterway Transport in Vietnam
}

\author{
Tan Vinh Nguyen ${ }^{1} \&$ Hoang Phuong Nguyen ${ }^{1}$ \\ ${ }^{1}$ Academy of Politics Region II, Ho Chi Minh City, Vietnam \\ Correspondence: Hoang Phuong Nguyen, Academy of Politics Region II, Ho Chi Minh City, Vietnam.
}

Received: April 19, 2020

Accepted: May 24, 2020

Online Published: June 16, 2020

doi:10.5430/rwe.v11n3p151

URL: https://doi.org/10.5430/rwe.v11n3p151

\begin{abstract}
Inland waterway transport (IWT) plays an important role in the cause of socio-economic construction and development and national defense during the period of national renewal and international economic integration. With abundant infrastructure resources, inland waterway transport is a strong transport form of Vietnam, and is considered a "locomotive" in the strategy of the transport industry. The IWT system of Vietnam is well performing its duties. The share of the IWT in Vietnam is among the highest in the world and the transport volume is still on the rise. This encouraging result is due to the main waterway network in the North and the South that currently serves the two most economically and spearhead locomotives of Vietnam. However, the development potential of IWT in Vietnam has not been optimally exploited and still limited. The main reason is due to the weak enforcement of current regulations because of overlapping legal system; Institutional framework faces many shortcomings, such as the current regulatory management sector, which lacks a formal mechanism for consultation with professional knowledge and expertise; The financial support framework is unclear and unsustainable as no user fee collection is used to support the infrastructure management activities of the Vietnam Inland Waterway Administration or lack of capital to build infrastructure development, the role of participation of private enterprises is limited.Therefore, improving the effectiveness of institutional structure, strengthening the framework and legal regulations as well as innovating financial mechanisms are essential for the sustainable development strategy of Vietnam's inland waterway transport industry in the period 2020-2030. The paper emphasizes the study of the development status of IWT system in Vietnam to highlight the role of reform solutions. The focus is on the institutional framework of infrastructure management and sector regulation, improving the enabling environment by disseminating laws and regulations in the industry, efficient distribution of capital resources ensures transparency and sustainability. The author has analyzed and comprehensively assessed the challenges that the inland waterway transport industry is facing, especially the pressure on the legal framework, institutional structure and policies that are inherently limited, also recommends for a reform program to support the IWT industry to develop in terms of both scale and technical level.
\end{abstract}

Keywords: Inland Waterway Transport (IWT), institutional and financial solutions, sustainable development strategy, Vietnam

\section{Introduction}

Inland waterway transport (IWT) is of strategic importance to Vietnam's transportation system. This method handles nearly one fifth of the domestic cargo traffic and is equivalent to $80 \%$ of the freight volume (ton-km) by road (V. V. Pham \& Hoang, 2019). IWT industry has grown and improved significantly in recent years. Not only are the transport contributions worthwhile, IWT will bring about more inclusive economic, environmental and social benefits(Wiegmans \& Konings, 2016). IWT transports about $17.1 \%$ of Vietnam's domestic freight volume and handles nearly $19 \%$ of the freight.This is a very high rate according to international standards and the rate of undertaking domestic goods of Vietnam is more than double that of China and the United States and the European Union where inland waterways are also a popular mode of transport (Wiegmans \& Konings, 2015). Immediately after joining the international economic community in the late 1980s, Vietnam considered the development of inland waterway transport as one of the top priorities to promote economic growth. Despite the limited budget, Vietnam has made great strides in developing inland waterway transportation by effectively exploiting natural conditions from the river and canal system. Notably, IWT's traffic volume has increased by 47\% between 2010 and 2016 (Utomo \& Mateo-Babiano, 2015). 
IWT routes are also directly connected to major domestic ports - this is another important cause contributing to the above results. In fact, IWT and coastal shipping currently account for three-fourths of the domestic freight volume. The types of cargo transported by IWT conforms to global standards, with bulk cargoes accounting for the majority. Many types of bulk goods with relative weight are also the objects of this method (G. Dang \& Pheng, 2015). Many production units in rural areas of Vietnam depend on IWT such as fishing enterprises, timber production, livestock and poultry, sugarcane and industrial crops. Container traffic is also increasing and private logistics companies have the potential to play a bigger role in IWT through the transport of higher-value industrial and consumer goods. Although this sector may still account for only a small proportion of the IWT's total traffic volume.IWT system in Vietnam is well performing its duties (Konings \& Wiegmans, 2016). The proportion of goods taken by IWT in Vietnam is much higher than that of any other country in the world and the traffic volume is still on the rise. This encouraging result is due to the main waterway network in the North and the South that currently serves the two most economically and spearhead locomotives of Vietnam.Success as a transportation service provider is largely based on the capacity, skills, and business performance of transportation service providers, managers, and workers in the industry. In addition, it is necessary to recognize the role of the government in creating an "enabling environment" for the sector's success, by issuing specific policies on infrastructure network management and regulate IWT activities (Howe et al., 2016; Mubarik \& Zuraidah, 2019).

The inland waterway fleet currently has more than 170,000 vehicles, most of which are small ships. However, the number of large and specialized vessels is increasing (X. P. Nguyen \& Pham Nguyen, 2019). International experience shows that these vehicles better meet the needs at lower costs. However, these vehicles require high standard waterways to accommodate the higher investment costs for the fleet as well as the mechanization of operations at the port. Most of the rotation takes place over 7,000 km of national inland waterways under central management (Nguyen \& Pham, 2019). However, only less than 30\% of this network's length is capable of serving barges with tonnage greater than 300 tons -This is a very modest rate compared to the most successful commercial water transport networks in the world (H. P. Nguyen, 2020b). The size of vessels in Vietnam is not large due to the shallow depth of canals, the size of the channel is small and the clearance is low.Many ports have outdated facilities and low level of mechanization, or poor maintenance, or poor inland connectivity. Meanwhile, all IWT networks of China, Europe and the United States are developed appropriately for vessels (or convoys) with a tonnage of more than 1,000 tons to operate, usually the payload of these vehicles is even greater (X. P. Nguyen, 2019).

Upgrading and maintaining IWT infrastructure network plays a strategic role in helping Vietnam connect directly with seaports to serve export needs. It contributes to promoting the trend of container shipping of new industries, while maintaining and promoting the environmental advantages of water transport,including lower greenhouse gas emissions per ton of freight (Hoang\&Chau, 2018). Continuous and long-term investment and maintenance is crucial for high-quality inland waterways, be able to maintain a competitive advantage with the upgraded road system and contribute to enhance the commercial competitiveness (Smajgl et al., 2015). Maintaining the strategic role of IWT in Vietnam depends on investing in infrastructure to receive larger, specialized and modern vessels, which requires traffic channels for ships to travel safely and reliably, without any rational and mechanized loading and unloading at ports and wharves. Integration into international logistics supply chains requires the creation of logistics centers and dry ports along inland waterways, with good connectivity to other modes of transport,especially the main road traffic network (Chandra, Shiva Harun, \& Reshma, 2017). However, Vietnam's waterways are facing a serious shortage of investment in infrastructure compared to demand and investment in other modes of transport. Increasing investment and effective management of the infrastructure network plays a key role in maintaining the competitive advantage of IWT. Investments in improving and maintaining the network of inland waterway infrastructure play a decisive role in helping Vietnam connect directly with seaports to serve export needs. This will also promote the trend of container shipping by new industries, while maintaining and promoting the environmental advantages of water transport, including lower greenhouse gas emissions per ton of freight. To have a solid base for large investments in modern ship and port systems. It is necessary to create trust for port operators and fleets about the safety and reliability of traffic channels, signal buoys and unreasonably static bridges and ports will be well connected in the future (V. T. Pham, 2019). The integration of IWT into Vietnam's international logistics supply chains requires actively encouraging the formation of logistics centers and dry ports along inland waterways, which are well connected with other modes of transport, especially the main road transport network (Hoang Phuong, Minh Tuan, \& Minh Tuan, 2019). The policies and plans for IWT development of the Government of Vietnam are very active and show high determination. The challenge is that Vietnam must ensure the mobilization of capital for operation and maintenance of inland waterway transport infrastructure after 2020, ensure that these funds are managed and used effectively, have sufficient investment capital to upgrade the infrastructure and improve the capacity of IWT in terms of both technical and market aspects (G. Dang \& Pheng, 2015). 
Vietnam has another bigger challenge, which is to ensure the enforcement of current laws and regulations, for example, regulations on registration of inland watercraft, overloading of vehicles, dangerous operation of vessels, inappropriate construction of inland wharves. The widespread non-compliance with the law indicates that state management should focus on the implementation and enforcement of important safety and environmental regulations. The fact that many ministries and agencies participate in the management is considered an obstacle to the development of Vietnam's inland water transport. However, this situation is more of a management challenge than a organizational constraint (V. L. Dang \& Yeo, 2018). Such overlap reflects a just and sometimes competing interest in the waterway transport sector,including issues related to traffic flow, water supply and drainage, irrigation, fishing and aquaculture, and eco-tourism. Inland waterway transport infrastructure management officials should actively coordinate with other inter-ministerial agencies to harmonize interests (if possible) and resolve differences.

Thus, relying only on natural conditions will likely diminish the competitive advantage of the industry. To realize the enormous potential of waterways in reality, Vietnam needs to focus on investing in institutional structure, strengthening the legal framework and regulations as well as improving the financial mechanism. The paper analyzes and comprehensively assesses the challenges that the inland waterway transport industry is facing. In addition, a reform program including sectoral development measures is proposed by the Government of Vietnam with the aim of improving the "favorable environment" in order to support the IWT industry to develop both in scale and technical level.The paper emphasizes the need for reform measures, with an emphasis on the institutional framework such as separation of infrastructure management and regulatory regulatory functions; improving the enabling environment by releasing a manual of industry laws and regulations to make them more accessible to users; transfering a part of funding for road transport to inland waterways and build a transparent roadmap,effective to encourage the private sector to participate in providing infrastructure as well as operating and maintenance services in this area. This paper focuses on three aspects of IWT management: Legal framework; institutional structure; and financial framework. The research team analyzes the actual situation and proposes solutions in each area to enhance the favorable environment for the industry. The legal framework is the system of Laws, Decrees, Decisions and Circulars of Vietnam's Ministry of Industry on the IWT operation management. Institutional structure refers to the structure of public and private organizations involved in the governance, regulation and operation of IWT sector.

\section{Roles and Infrastructure of Inland Water Transport}

\subsection{The Importances of Inland Water Transport}

IWT accounts for about $17.1 \%$ of Vietnam's total domestic cargo, accounting for about $18.9 \%$ of the freight volume (including tons and tonnage). Table 1 based on official statistics shows that IWT transports about 212.5 million tons / year with an average distance of $212 \mathrm{~km}$. Road transport has the largest transport volume $(957.5$ million tons or $77.2 \%$ of the total transport volume) but mainly transports with relatively short distance (average of $59 \mathrm{~km}$ ) (Utomo \& Mateo-Babiano, 2015). Coastal shipping accounts for a smaller proportion (64.8 million tons or $5.2 \%$ of the total) but with a much longer distance, averaging over $2,000 \mathrm{~km}$. Railway accounts for a relatively small proportion of freight transport in terms of both the transport volume $(0.4 \%)$ and the rotating volume (1.3\%) (Shultz \& Peterson, 2019).

Table 1. Inland freight flow by mode (2016) (V. L. Dang \& Yeo, 2018)

\begin{tabular}{cccccc}
\hline $\begin{array}{c}\text { Mode of } \\
\text { transport }\end{array}$ & $\begin{array}{c}\text { Shipping } \\
\text { volume } \\
\text { (million tons) }\end{array}$ & $\begin{array}{c}\text { Rate of } \\
\text { undertaking } \\
\text { transport } \\
\text { volume }(\boldsymbol{\%})\end{array}$ & $\begin{array}{c}\text { Volume of } \\
\text { turnover (Bil } \\
\text { tons-km) }\end{array}$ & $\begin{array}{c}\text { Rate of } \\
\text { take-over of } \\
\text { the circulating } \\
\text { volume }(\%)\end{array}$ & $\begin{array}{c}\text { Average } \\
\text { transport } \\
\text { distance }(\mathbf{k m})\end{array}$ \\
\hline Road transport & 957,5 & 77,2 & 56,5 & 23,7 & 59 \\
\hline $\begin{array}{c}\text { Railway } \\
\text { transport }\end{array}$ & 5,2 & 0,4 & 3,2 & 1,3 & 615 \\
\hline IWT & 212,5 & 17,1 & 45,1 & 18,9 & 212 \\
\hline $\begin{array}{c}\text { Coastal } \\
\text { shipping }\end{array}$ & 64,8 & 5,2 & 132,6 & 55,7 & 2333 \\
\hline $\begin{array}{c}\text { Transport by } \\
\text { air }\end{array}$ & 0,3 & 0,0 & 0,7 & 0,3 & \\
\hline TOTAL & 1240,3 & 100 & 238,1 & 100 \\
\hline
\end{tabular}


Notably, coastal transport and IWT account for about three-fourths of the total inbound volume. This is a very high proportion by international standards and has many advantages in terms of transport costs and community costs. It should be noted that the "adoption ratio of the modalities" nationwide is an aggregate statistic and does not reflect the "market share" of this sector.The concept of market share is used with caution when many different modes of transport compete with each other in a market: usually freight forwarding in a specific region or area. While the road system extends throughout Vietnam, the waterway transport networks are only regional in nature. IWT can not compete with market share if the area is not suitable for transportation by waterway. Therefore, although the share of IWT nationwide is $18.9 \%$, the market share of this mode in some areas must be much higher and IWT is the main mode of transportation in the areas (Nguyen, 2019). The area has the busiest waterway. However, Vietnam currently has very few statistics on transport routes, so it is difficult to give accurate estimates. IWT has increased the proportion of freight every year and currently accounts for a larger share of the total turnover. IWT's traffic volume increased by $47 \%$ between 2010 and 2016, from 144.2 million tons to 212.5 million tons (H. P. Nguyen, 2019). The share of IWT in total traffic volume has increased from $14.5 \%$ to $18.9 \%$ since 2010 . But the volume and the share of cargo transport by road has increased faster than IWT.Vietnam's water transport has a much higher proportion of domestic cargo handling than China, the United States and the European Union. Vietnam has about 8,000 km of important commercial waterways. These routes contribute more than double the freight handling rate of any of the three countries / regions mentioned above (Table 2). Particularly in the European Union, only Dutch waterways have a higher rate of undertaking freight transport than Vietnam.

Table 2. Waterways in different countries (Banomyong, Thai, \& Yuen, 2015)

\begin{tabular}{ccccc}
\hline & Vietnam & China & US & EU \\
\hline $\begin{array}{c}\text { Transportable canals and rivers (approximate } \\
\text { number of km) }\end{array}$ & 26500 & 123000 & 40000 & 35000 \\
\hline Main IWT routes (approximate km) & 8000 & 42000 & 18000 & 8000 \\
\hline $\begin{array}{c}\text { The share of IWT assumed in total domestic } \\
\text { freight (tons-km) }\end{array}$ & $19 \%$ & $7-8 \%$ & $5-7 \%$ & $6-8 \%$ \\
\hline
\end{tabular}

\subsection{Infrastructure of Inland Water Transport}

Vietnam has more than 170,000 inland vessels, the proportion of larger and specialized ships is on the rise. About $97 \%$ of the ships are dry cargo barges with an average load of 90 DWT. The tanker tonnage is 236 DWT and container ship is 1,171 DWT (H. P. Nguyen, 2020a). Most vessels are of medium weight, especially for dry bulk vessels, including tens of thousands of very small barges with a tonnage of only 5-20 DWT. In the period of 2014-2017, the number of ships increased by 7\%, but the total capacity increased to $43 \%$ due to an increase in the average tonnage of all types of ships (H. P. Nguyen, 2020b). Government policies to encourage fleet upgrades have yielded positive results. The number of large vessels (over 1,500 DWT) has nearly doubled in three years, from 696 ships in 2014 to 1,287 ships in 2018 (H. P. Nguyen, 2019). Of the total fleet capacity, the proportion of these large vessels increased from $11 \%$ to $15 \%$ for dry cargo ships, from $19 \%$ to $22 \%$ for tankers and from $43 \%$ to $53 \%$ for container ships (T. Y. Pham \& Yeo, 2019). IWT enterprises are clearly showing benefits in terms of scale and level of specialization. If the length of high-class waterways (grades I and II) can be extended, this trend will increase even more.

Vietnam has many inland ports and wharves but the infrastructure and equipment of most ports are poor and often do not connect well with roads. At the beginning of 2017, Vietnam had about 7,257 ports and inland wharves, of which about 4,750 were located on the national waterway network. Among the inland ports and wharves, 3,492 have been licensed by VIWA and 1,217 are unlicensed. The total number of inland waterway ports is 306, including 254 ports located on national waterways and 52 ports located on inland waterways (V. T. Pham, 2019). 
Table 3. Domestic fleet of ships according to the classification list (2017) (Vietnam's Transport Sector, 2017)

\begin{tabular}{cccccc}
\hline Type of ship & $\begin{array}{c}\text { Number } \\
\text { of ships }\end{array}$ & $\begin{array}{c}\text { Total load } \\
\text { (DWT) }\end{array}$ & $\begin{array}{c}\text { Average Load } \\
\text { (DWT / vessel) }\end{array}$ & $\begin{array}{c}\text { Total ship } \\
\text { capacity } \\
\text { (cv) }\end{array}$ & $\begin{array}{c}\text { Average } \\
\text { capacity } \\
\text { (cv/ ship) }\end{array}$ \\
\hline Dry cargo ship & 162865 & 14591035 & 90 & 8595407 & 53 \\
\hline Tankers & 2363 & 558158 & 236 & 415102 & 176 \\
\hline Container ship & 1038 & 1215096 & 1171 & 481668 & 464 \\
\hline Other & 1134 & 78082 & 69 & 134288 & 118 \\
\hline Total & 167400 & 16442371 & 98 & 9626465 & 58 \\
\hline
\end{tabular}

The throughput of most ports is less than the potential of the facilities and the modern handling measures used by the port. Many ports have outdated facilities and low level of mechanization, are poorly maintained or connected to inland areas. In fact, there are 11 major cargo ports for IWT in the North and about 18 ports in the South. Inland wharves and piers have many different levels of quality. Most inland wharves, licensed or unlicensed, are at a very basic level, only manually loading and unloading goods to river banks or canals. However, a number of specialized inland wharves are dedicated to a specific product and are therefore reasonably invested in equipment and maintenance. The large number of inland ports and wharves makes IWT system accessible but need to be managed. Not all shippers want or need large barges. Many rural communities have stocking points at small mills, wood yards, fertilizer stores, etc., located along river banks and canals and have limited capacity. Small barges, suitable for the size of the local consignment, can access inland wharves and take cargoes to the gathering points to merge onto larger barges or directly to the destination. Because many industrial facilities are located along the river banks, spontaneous wharves with simple designs and low investment costs have increased rapidly. Inland docks can be constructed at a very basic level. In some berths, there is a ramp and a small mobile crane and in others, loading and unloading is even done manually using board decks or coaches. Therefore, it is possible to spill / dump some materials into waterways (Hoang \& Pham, 2018). Many inland wharves do not have temporary permits or are built on farmers' land or are only used for self-unloading of goods. If the terminals are placed in an inappropriate location, they can cause insecurity or congestion.

\section{Planning for Development of Inland Water Transport}

The policy of the Government of Vietnam to strengthen the role and effectiveness of IWT is most clearly stated in the 2014 Ministry of Transport's Decision on Restructuring of inland waterways. Decision 4910/14 sets out the main objectives, orientations and policies of the industry and steps to be taken. These policies aim to confirm the need for coordinated actions and policies for infrastructure, fleets, management, organization, funding and promotional activities for the industry(Vu \& Hartley, 2018).

The restructuring plan includes seven "policy directions" that need to be implemented to align with the goals: (1) Modernize and develop a sustainable IWT system and promote benefits to transport service users and the community. (2) Developing IWT infrastructure more systematically, identifying specific construction objectives, improving management requirements, improving capacity, cooperating with local authorities. (3) Develop IWT fleets in accordance with national standards but encourage specialized vessels to serve specific cargo and transport routes, develop container fleets, as well as multipurpose vessels. (4) Manage IWT infrastructure development more closely, modernize assets, establish national database systems, with more effective compliance and safety measures, etc. (5) Use resources to carry out advanced, scientific, efficient and safe inland waterway maintenance, together with increasing demandand mobilizing resources involved in the maintenance and management and application of rapid remedies. (6) Improve traffic safety through effective regulation and compliance of ships and crew as well as waterway traffic management to reduce traffic accidents and casualties. (7) Restructuring IWT and its departments and agencies, consolidating organizations responsible for maintenance, giving more autonomy to training institutions and strengthening the capacity of the inland waterway management board in association with the Vietnam National Shipping Agency.

The goals and policy directions are very strong and comprehensive, many of which have been set out in the 2014 Sector Restoration Plan have been successfully implemented. There is a clearer division between the functions of the Government, the Ministry of Transport and the Department of Vietnam Railway Department; between IWA and new companies signed a contract with IWA to manage and maintain the infrastructure; as well as between the regulatory 
roles of government agencies and commercial enterprises.Many decrees and circulars also reinforce the obligations of governing bodies to promote or encourage industry development. Unfortunately, in many cases, amending the legal structure to reflect the restructuring direction makes the restructuring process more complicated (N. B. Dang, Momtaz, Zimmerman, \& Hong Nhung, 2017).

The quantitative goals in the 2014 Decision on Transport Growth are unrealistic and unmet ambitions. The goal is to double the share of the mode of water transport by 2020. National statistics show that the volume of rotation has increased significantly from $14.5 \%$ to $18.9 \%$ since 2010 . However, the goal of doubling does not seem feasible. IWT has a dominant market share in major transport corridors where IWT is one of the options. It seems computational that the national average cannot be doubled when in most regions without water transport. If the government wishes to achieve multimodal goals, it is more reasonable to set specific goals for IWT areas or corridors. In terms of fleet structure goals, there was an increase in the number and percentage of larger ships, but this trend depends on the investment of private shipping businesses and not on the direction of the government. Finally, the objectives of infrastructure investment under the line of state management, also encounter serious shortage of investment capital.

The updated draft master plan for 2018 of IWT infrastructure to 2020 has been completed and is waiting for approval. The updated Draft Master Plan reinforces the policy directions established in the 2014 restructuring plan and adds details about the specific measures proposed. The plan also sets more realistic growth targets than those set in 2014. Therefore, the Government's plans for IWT can be said to remain positive and ambitious in both system and policy development. The research team supports the policies of the Government of Vietnam and recommends some recommendations in this article as a basis for support.

\section{Situation of Legal Framework, Institutional Structure and Financial Framework for Inland Waterway Transport}

\subsection{Legal Framework}

State management activities of IWT (regulations, institutional and financial structures) are comprehensively regulated in the decentralized legal system, structured in accordance with Vietnamese legal standards. A law (or Code) is passed by the National Assembly and is the highest form of legal document (outside the Constitution).Forms of bylaws to support a Law or a Code include:The Decree lays down the provisions on the content implementation of the Law; The decision directs relevant policy issues, and the Circular provides detailed guidance on how to apply specific aspects of existing laws and decrees(Kim Dung, Bush, \& Mol, 2017).

The current legal framework regulating IWT activities is based on the Law on Inland Waterway Transport (2004) and was amended and supplemented in 2014, together with 8 Decrees of the Government of Vietnam, a Decision of the Prime Minister and about 40 Circulars of the Ministry of Transport. Therefore, the legal framework for IWT activities of Vietnam is integrated and built according to the hierarchy, in which the legal principles, administrative structure, policy direction and legal obligations are intertwined. The following hierarchy of legal documents will be collectively referred to as the Legal Framework (To \& Kato, 2018). However, many legal documents in the Legal Framework are usually issued individually; These documents are not codified in the same set of legal documents governing this field. The focus of this section is to assess the regulatory features of the Legal Framework in relation to four broad categories: (1) the strategic objective of the regulation; (2) scope of regulation; (3) technical regulatory structure (safety and environment); and (4) the legal structure of the economy.

The law sets out detailed technical, safety and environmental regulations that apply to transport businesses, vehicles, crew members and vehicle drivers, traffic rules and port regulations. The technical regulations are in Chapters 3 to 6 of the Law on Inland Waterway Transport, which are divided according to each applicable object mentioned above. Table 4 summarizes the rules that apply to each target group. For ease of reference, the regulations are cited in accordance with the ordinal numbers of the Chapter in the 2004 Law on Inland Waterway Transport. However, the content described in the summary table covers elements of the decree and the applicable circular. 
Table 4. Structure of technical regulations for IWT activities (National Assembly, 2014)

\begin{tabular}{|c|c|}
\hline $\begin{array}{l}\text { Chapter in Law and } \\
\text { governing scope }\end{array}$ & Contents of technical, safety and environmental regulations \\
\hline Chapter 3: Media & $\begin{array}{l}\text { Provisions on requirements for: vehicle registration; vehicle registration; facilities } \\
\text { for building and repairing vehicles and importing vehicles. The law provides } \\
\text { specific regulations for each type of vehicle, including } 4 \text { groups of vehicles } \\
\text { classified by size.These regulations relate to the vehicle's quality, technical safety } \\
\text { and environmental protection standards. The Ministry of Transport's Circular } \\
75 / 2014 \text { and } 48 / 2015 \text { provide guidance on specific regulations and legal grounds } \\
\text { for vehicle registration cancellation. }\end{array}$ \\
\hline $\begin{array}{l}\text { Chapter } \quad 4: \text { Crew } \\
\text { members and vehicle } \\
\text { drivers }\end{array}$ & $\begin{array}{l}\text { Regulations related to the professional conditions of crew members and vehicle } \\
\text { drivers (crew members apply to means of group } 1 \text {, motor vehicle drivers apply to } \\
\text { vehicles of category 2).The content of the legal provisions covering the titles and } \\
\text { standards of crew members; training, diplomas and professional certificates; } \\
\text { conditions for crew members and vehicle drivers.Circulars No. 56/2014 and } \\
02 / 2017 \text { provide in detail and update these contents. Circular } 47 / 2015 / \mathrm{MOT} \text { and } \\
\text { Circular 04/2017 /MOT provide regulations and update the minimum safety norms } \\
\text { for crew members and professional capacity for vehicles. }\end{array}$ \\
\hline Chapter 5: Traffic rules & $\begin{array}{l}\text { Stipulating rules to ensure safe traffic, traffic rules and signals of vehicles, } \\
\text { warnings and methods of handling in dangerous situations; itinerary under } \\
\text { restricted vision conditions and where the flow intersects, the curve sharply folds; } \\
\text { the priority of special-duty vehicles; means of avoiding each other when going in } \\
\text { the opposite direction; vehicles overtaking each other; anchoring means.Circular } \\
40 / 2010 \text { /MOT and Circular 30/2017 /MOT refer to the regulation and control of } \\
\text { traffic assurance in special situations. }\end{array}$ \\
\hline $\begin{array}{l}\text { Chapter 6: Inland ports } \\
\text { and wharves }\end{array}$ & $\begin{array}{l}\text { Regulation regulating technical activities of inland ports, wharves, port authorities } \\
\text { and inland waterway pilots; responsibility of captain, pilot and vehicle owner when } \\
\text { having losses. The Ministry of Transport's Circular 50/2014 / MOT details the } \\
\text { process of approving and deploying plans and projects for inland ports. }\end{array}$ \\
\hline
\end{tabular}

Table 5. Legal and regulatory framework: Vehicle classification system (National Assembly, 2014)

\begin{tabular}{ll}
\hline \multicolumn{1}{c}{ Vehicle level } & \multicolumn{1}{c}{ Vehicle characteristics } \\
\hline Group 1 & $\begin{array}{l}\text { Vehicles without engines of a gross tonnage of over 15 tons; Means with engines } \\
\text { of a main engine of over } 15 \text { horse power and a vehicle with a capacity of over } 12 \\
\text { people }\end{array}$ \\
\hline Group 2 & $\begin{array}{l}\text { Vehicles without engines of a gross tonnage of between } 5 \text { tons and } 15 \text { tons, means } \\
\text { with engines with total main engine capacity of between } 5 \text { horse power and } 15 \\
\text { horse power or with a capacity of between } 5 \text { people and } 12 \text { people }\end{array}$ \\
\hline Group 3 & $\begin{array}{l}\text { Vehicles without engines of a gross tonnage of between } 1 \text { ton and under } 5 \text { tons or } \\
\text { with a capacity of between } 5 \text { and } 12 \text { people, means with engines of main engine } \\
\text { capacity of under } 5 \text { horse power or with a capacity of under } 5 \text { people }\end{array}$ \\
\hline Group 4 & $\begin{array}{l}\text { Rudimentary means with a gross tonnage of under } 1 \text { ton or carrying a capacity of } \\
\text { under } 5 \text { people. }\end{array}$ \\
\hline
\end{tabular}

The Minister of Transport has a legal responsibility for managing the regulations related to the quality, technical safety and environmental protection standards of vehicles. The larger the media, the higher the standards need to be met. For example, vehicles from Group 4 do not require registration, while vehicles of Group 1 and Group 2 not only require vehicle registration but are only allowed to operate after being checked for technical and environmental safety. Table 5 summarizes the group of vehicles regulated in the Inland Waterway Law. The requirements for seafarers are also adjusted by vehicle type (Chapter 4 of the Law on Inland Waterway Traffic).

Technical regulations on water management and maintenance are specified in circulars issued by the Ministry of 
Transport. Circular 15/2016 / MOT regulates inland waterway management and Circular 25/2016 / MOT updating, amendingand additional technical-economic norms for tasks and activities classified by categories for the management and maintenance of inland waterway networks. The regulation also refers to the process of applying these norms. One noteworthy content in the legal documents is that while environmental regulations prohibit the discharge of wastes such as coal dust and sand into channels. Currently, Vietnam has not yet developed standards on engine performance and emission standards for engines of specific transport vehicles (H. P. Nguyen, 2020a). The European Union has paid attention to the development of these regulations for all modes of transport and offers programs to support the upgrading of engines of inland water fleets.

The legal framework governing IWT activities in Vietnam is highly comprehensive. In general, important legal provisions in this area play a role in encouraging environmental and safety development for IWT. The strategic goal of the legal framework recognizes the scope of public interest in IWT and is relevant in many ways.The legal framework governing IWT activities in Vietnam is highly comprehensive. In general, important legal provisions in this area play a role in encouraging environmental and safety development for IWT. The strategic goal of the legal framework recognizes the scope of public interest in IWT and is relevant in many ways.

However, the hierarchical structure of the legal system shows that the legal framework is still quite complex and fragmented. The hierarchy of links between laws, decrees, circulars and decisions will inevitably lead to the existence of too many regulations, duplication and repetition. Therefore, the "external form" is not much "friendly" for business operators and potential investors. However, the positive content of the legal provisions shows the legal support and does not create any significant obstacles to the development of this field. The legal framework itself is also referring to the government's legal system, which is not limited to IWT. Therefore, it is not realistic to expect that a legal framework within the comprehensive socialist legal system that can be replaced in the transport sector will not be practical (Chen, Tabssum, \& Nguyen, 2019). The challenge and time for trying to change the legal system in Vietnam is not easy.

The most feasible approach to addressing the complexity of the legal system is to increase access to key aspects of the legal provisions in this field in easier ways. What is needed now is the need to reread the entire component of the existing legal system in order to find specific parts that apply to stakeholders or investors and understand what needs to be done to comply with these laws. It is very likely that vehicle owners - individual transport operators, do not fully understand these legal requirements. To improve the enabling environment for IWT activities, current laws and regulations need to be "interpreted" in the form of simpler handbooks for industry and investors to read. In this spirit, one of the Ministry of Transport's policy goals (Decision 4910/15) is to update and issue legal documents published in a more understandable form. Although Vietnam has developed a comprehensive legal framework, the level of compliance and enforcement of laws is an issue to consider (Hoang Phuong et al., 2019). From illegal sand mining to unlicensed vehicle mooring point, unregistered transport means, overloading, dumping waste of means of transport, negligent operators, industry stakeholders all acknowledge the situation of non-compliance and poor enforcement of the regulations.

\subsection{Institutional Structure}

The assignment of responsibilities in the IWT sector of Vietnam is generally clear and appropriate. The roles and responsibilities are specified by law. The research team identifies most of the features of this institutional structure as appropriate and in line with international practice. The main characteristics are analyzed in detail in each section below. Moreover, compare with some mechanisms in the three areas of comparison, if appropriate and focus attention on the areas that the World Bank thinks need to be considered for improvement or amendment. Most of these issues are related to the internal consolidation of the Vietnam Inland Waterway Administration (VIWA).Table 6 summarizes the current organizational structure. Dotted lines represent a plan to add to the existing structure: a third regional office and a fifth port authority are needed to support operations in the central region of Vietnam. 
Table 6. Three main groups of activities of the Vietnam Inland Waterway Administration(VIWA, 2020a)

\begin{tabular}{|c|c|c|}
\hline $\begin{array}{l}\text { Infrastructure management } \\
\text { activities }\end{array}$ & Regulatory activities & General activities (support) \\
\hline $\begin{array}{l}\text { - Classification, management and } \\
\text { maintenance of IWT } \\
\text { infrastructure; } \\
\text { - Setting standards and technical } \\
\text { regulations; } \\
\text { - Making sectoral master plans, } \\
\text { development plans and projects; } \\
\text { - Implementation of approved } \\
\text { development plans; } \\
\text { - Implement approved waterway } \\
\text { safety measures; } \\
\text { - Implementation } \\
\text { environmental plans, regulations } \\
\text { and EIA of projects; } \\
\text { - Supervising activities of } \\
\text { investors in IWT construction } \\
\text { projects; } \\
\text { - Coordinating with local } \\
\text { authorities and other agencies; } \\
\text { guide local agencies to manage } \\
\text { and maintain local waterways; } \\
\text { - Notice the closure and reopening } \\
\text { of waterways and ports; } \\
\text { - Flood and storm prevention and } \\
\text { response measures; } \\
\text { - Summary of statistics on } \\
\text { national waterways and ports, } \\
\text { market research; } \\
\text { - Encourage the development of } \\
\text { passenger and cargo traffic by } \\
\text { IWT; Propating and educating about } \\
\text { - Propagationt infrastructure } \\
\text { the IWT traffic } \\
\text { development plan and } \\
\text { regulations. }\end{array}$ & $\begin{array}{l}\text { - Drafting regulations on IWT and } \\
\text { issuing approved documents; } \\
\text { - Development of safety and } \\
\text { environmental regulations } \\
\text { including those related to energy } \\
\text { efficiency and climate change; } \\
\text { - Check infrastructure and } \\
\text { maintenance works; } \\
\text { - Licensing operations for ports } \\
\text { and marinas; } \\
\text { - Regulations on registration and } \\
\text { management of inland vessels; } \\
\text { - Regulations on minimum crew } \\
\text { size, conditions and professional } \\
\text { standards, and training and } \\
\text { certification requirements for IWT } \\
\text { operators (captains, supporters, } \\
\text { crew members); } \\
\text { - Drafting rules and regulations on } \\
\text { water transport; } \\
\text { - Regulations on protecting } \\
\text { customers for passengers and } \\
\text { goods (bill of lading, tickets); } \\
\text { - Monitor arrival and departure of } \\
\text { ports and enforcement of vessel, } \\
\text { crew and port regulations and port } \\
\text { loading and unloading operations; } \\
\text { - Investigating work-related } \\
\text { accidents; } \\
\text { - Participating in investigating } \\
\text { vessel accidents (as a lead by the } \\
\text { Waterway Police); } \\
\text { - Dissemination and education of } \\
\text { IWT laws and regulations. }\end{array}$ & $\begin{array}{l}\text { - International cooperation and } \\
\text { international treaties; } \\
\text { - Research and development in } \\
\text { IWT management and IT as well } \\
\text { as application use; } \\
\text { - Operate a database of } \\
\text { information on state management } \\
\text { and for individuals participating in } \\
\text { IWT; } \\
\text { - Encouraging associations and } \\
\text { non-governmental organizations } \\
\text { to participate in IWT; } \\
\text { - Planning and implementing } \\
\text { administrative reform programs; } \\
\text { - Inspecting facilities, resolving } \\
\text { complaints, preventing corruption } \\
\text { and wasting in IWT management; } \\
\text { - Human resource management of } \\
\text { IWT; } \\
\text { - Financial, accounting and budget } \\
\text { management of the Vietnam } \\
\text { Waterway Administration; } \\
\text { - Contacting other government } \\
\text { agencies upon request; } \\
\text { - Collaborate with other ministries } \\
\text { and local governments to } \\
\text { supervise the training and } \\
\text { certification of two vocational } \\
\text { training schools and colleges. }\end{array}$ \\
\hline
\end{tabular}

The research team found that most of the characteristics of this institutional structure were reasonable and consistent with established international practices. The assignment of duties between the central and provincial governments; between public and private sectors; relationship between the managing ministry and the attached agency between the Ministry of Transport and the VIWA; and the recent movement of having commercial contractors undertake some IWT infrastructure management contracts is not convincing. The key factor to improve the enabling environment for transport business units and investors is not to restructure IWT sector but to improve the performance of existing state management agencies, especially the VIWA. It will still be a key implementing agency, mandated by the government under MOT supervision over both core areas, infrastructure management and regulatory regulation. Therefore, most of the areas that can be improved are related to capacity building of VIWA.

\subsection{Financial Framework}

The Law on Inland Waterways 2004 (amended in 2014) defines the financial source for the management and maintenance of inland waterways simply from the State Budget and other sources as prescribed by law. Decree $51 / 2005$ provides a more detailed definition of management and maintenance, including public management and public services as well as regular and regular maintenance. Decree No. 51/2005 also provides that:Financial resources must be sufficient and stable to ensure the management, maintenance and protection of IWT infrastructure. 
For national inland waterways, these sources come from the central budget and other lawful sources; For local waterways, financial resources come from local budgets and other lawful sources; For specialized inland waterways or inland waterways invested outside the budget, these sources will be arranged by organizations and individuals that manage and use inland waterways. Financial sources include: (1) State budget (central and local budgets); (2) sources of charges for use of inland waterways for roads invested outside the state budget; (3) contributions from organizations and individuals; (4) non-state budget investment and other sources into inland waterways.

For more than a decade, IWT infrastructure construction has been almost entirely funded by ODA. If only ODA capital is mobilized, it will not ensure sufficient development capital in the long term. In the future, this source of capital will gradually decrease as an inevitable trend. Currently, there are no new projects on infrastructure in construction. A number of new projects have been proposed, however, these projects are not yet in the stage of technical dossier preparation and have not guaranteed funding for their implementation. Although appropriate funding mobilization planning is in place, public authorities (in this case VIWA) need to take an important initial preparatory step: prioritizing and project preparation. The cost of operating and maintaining the waterways of the Department of Natural Resources and Environment of Vietnam is completely based on the budget allocated from the national budget. Decision No. 47/2015 of the Prime Minister to increase capital sources for IWT infrastructure maintenance in the period 2016-2020(Weber \& Feltmate, 2016). In 2017, the budget for operation and maintenance of water transport infrastructure increased by nearly $80 \%$ compared to 2013; However, many of these activities could not be implemented due to lack of capital. No fees have been collected from users of infrastructure and waterway transport routes. The port authority's inland port infrastructure fee collection is almost enough to cover administrative costs. The previous proposals on setting up the Waterway Maintenance Fund were notable. Funds for this Fund may be allocated from the annual budget, fees collected from water users, and contributions from IWT beneficiaries (such as owners of riparian assets and people using transportation services) as well as from transportation fuel taxes. Port investment and operation - maintenance costs have been transferred to private enterprises after the equitization process in recent years(Lebovics, Hermes, \& Hudon, 2016).

For more than a decade, IWT infrastructure construction has been almost entirely funded by ODA(Raschky \& Chantarat, 2020). Less than $1 \%$ of investment in infrastructure construction is funded by the Government of Vietnam and is mainly used to prepare IWT Master Plan and project preparation (Table 7).

Table 7. Investment expenditure of Vietnam Inland Waterway Administration (2010-2019) (VIWA, 2020b)

\begin{tabular}{|c|c|c|c|c|c|c|c|c|}
\hline \multirow{2}{*}{\multicolumn{2}{|c|}{$\begin{array}{l}\text { Construction of inland waterway } \\
\text { transport infrastructure }\end{array}$}} & \multicolumn{7}{|c|}{ Cost (VND Billion) } \\
\hline & & 2010 & 2011 & 2012 & 2013 & 2014 & 2015 & 2016-2019 \\
\hline 1 & Infrastructure 1 & ject for I & T transp & tation & & & & \\
\hline 1.1 & $\begin{array}{l}\text { Transport } \\
\text { development } \\
\text { project in the } \\
\text { Northern Delta } \\
\text { region (WB6) }\end{array}$ & 525 & 525 & 525 & 525 & 525 & 525 & - \\
\hline 1.2 & $\begin{array}{l}\text { Mekong Delta } \\
\text { Transport } \\
\text { Development } \\
\text { Project (WB5) }\end{array}$ & 586 & 586 & 586 & 586 & 586 & 586 & - \\
\hline 1.3 & \multicolumn{4}{|c|}{ Cho Gao Canal Upgrading Project: Phase 1} & 390 & 390 & & - \\
\hline 2 & $\begin{array}{l}\text { Master plan for } \\
\text { inland } \\
\text { waterway } \\
\text { transport }\end{array}$ & & & 3.80 & 3.04 & 1.67 & 3.38 & - \\
\hline \multirow[t]{2}{*}{3} & $\begin{array}{l}\text { Preparation of } \\
\text { investment } \\
\text { projects inland } \\
\text { waterway } \\
\text { transport }\end{array}$ & 3.86 & 1.81 & 2.40 & 1.00 & 2.00 & 6.38 & - \\
\hline & $\begin{array}{l}\text { Total cost of } \\
\text { infrastructure } \\
\text { construction }\end{array}$ & 1114.86 & 1112.81 & 1117.20 & 1505.04 & 1504.67 & 1120.76 & - \\
\hline
\end{tabular}


Ensuring capital construction investment for national waterways development is a key challenge for the Government of Vietnam As shown in Table 7, the actual average annual investment cost from all sources in the period 2010 2015 - the period in which three ODA projects (see section 1.1, 1.2 and 1.3 in table 7) is VND 1,246 billion. It is important to emphasize the two points mentioned above: almost all of the above capital is from ODA with a very small portion from the state budget. In addition, Vietnam has not yet made any capital construction investment for waterway development in the period of 2016 - 2019. It should also be noted that Vietnam has not implemented a public-private partnership project or any foreign direct investment project in this area. Table 8 shows the average annual basic investment cost from all sources in the period 2019 - 2030 proposed at VND 2,217 billion, an increase of $180 \%$ compared to the annual average of the period 2010 - 2015. Of the proposed investment capital for the period to 2030 , more than $50 \%$ (VND 15,000 billion) is from private enterprises investing in inland port and port development projects.

Table 8. Investment expenditure of Vietnam Inland Waterway Administration (2010-2019)(VIWA, 2020b)

\begin{tabular}{|c|c|c|c|c|c|c|c|c|c|}
\hline \multirow{2}{*}{\multicolumn{2}{|c|}{$\begin{array}{l}\text { Operation \& Maintenance of } \\
\text { inland water transport }\end{array}$}} & \multicolumn{8}{|c|}{ Cost (VND Billion) } \\
\hline & & \multirow{2}{*}{$\frac{2010}{\text { tenance }}$} & \multirow[t]{2}{*}{2011} & \multirow[t]{2}{*}{$2012-2014$} & \multirow[t]{2}{*}{2015} & \multirow[t]{2}{*}{2016} & \multirow[t]{2}{*}{2017} & \multirow[t]{2}{*}{2018} & \multirow[t]{2}{*}{2019} \\
\hline 1 & Regular operation \& mai & & & & & & & & \\
\hline 1.1 & $\begin{array}{l}\text { Regular management } \\
\text { and maintenance of } \\
\text { inland waterway } \\
\text { transport infrastructure }\end{array}$ & 185.6 & 225.95 & - & 266.43 & 256.49 & 278.8 & 355.8 & 399.3 \\
\hline 1.2 & Dredging & 34.9 & 38.3 & - & 84.4 & 110.4 & 156.24 & 31.8 & 83.2 \\
\hline 1.3 & $\begin{array}{l}\text { Regulating and } \\
\text { organizing traffic }\end{array}$ & 10.5 & 19.2 & - & 30.88 & 52.12 & 70.7 & 83.1 & 91.4 \\
\hline 1.4 & $\begin{array}{l}\text { Management and operatio } \\
\text { ship lock }\end{array}$ & of Rach & Chanh & - & - & - & 7.3 & 10.58 & 9.4 \\
\hline 1.5 & $\begin{array}{l}\text { Survey to manage and } \\
\text { publish the route }\end{array}$ & 0.98 & 1.7 & - & 16.68 & 26.92 & 40.4 & 30.6 & 27.3 \\
\hline \multicolumn{2}{|c|}{$\begin{array}{l}\text { Sub-total commissioning \& } \\
\text { regular maintenance }\end{array}$} & 231.98 & 285.15 & - & 398.39 & 445.93 & 553.44 & 511.88 & 610.6 \\
\hline 2 & Irregular expenditure & & & & & & & & \\
\hline 2.1 & $\begin{array}{l}\text { Repair and move signal } \\
\text { equipment }\end{array}$ & 4.70 & 4.57 & - & 5.79 & 4.26 & 10.8 & 12.5 & 6.4 \\
\hline 2.2 & $\begin{array}{l}\text { Producing, adding and } \\
\text { replacing signal } \\
\text { equipment }\end{array}$ & 7.50 & 14.20 & - & 10.65 & 19.97 & 67.8 & 178 & 125.1 \\
\hline 2.3 & $\begin{array}{l}\text { Supply and replace solar } \\
\text { signal equipment \& } \\
\text { accessories }\end{array}$ & 3.90 & 0.2 & - & 18.65 & 23.56 & 28.4 & 31.16 & 23.9 \\
\hline 2.4 & $\begin{array}{l}\text { Repairing big } \\
\text { revetments }\end{array}$ & 3.6 & 3.5 & - & 19.68 & 15.16 & 11.98 & 37.8 & 67.5 \\
\hline 2.5 & Eliminate obstacles & 3.7 & 4 & - & 9.78 & 59.47 & 46.2 & 8.15 & 34.9 \\
\hline 2.6 & $\begin{array}{l}\text { Repair of waterway } \\
\text { management station }\end{array}$ & 2.97 & 5.5 & - & 3.9 & 1.6 & 2.51 & 18.9 & 7.88 \\
\hline 2.7 & \multicolumn{3}{|c|}{ Repair and improve water level devices } & - & & 5.87 & 11.45 & 11.9 & 14.5 \\
\hline 2.8 & $\begin{array}{l}\text { Overcoming floods and } \\
\text { storms }\end{array}$ & 0.50 & 0.40 & - & 14.32 & 0.00 & 14.2 & 3.04 & 5.5 \\
\hline 2.9 & $\begin{array}{l}\text { Build buoys and anchors } \\
\text { to avoid storms }\end{array}$ & & & - & 15.22 & 25.97 & 10.37 & 11.05 & \\
\hline 2.10 & $\begin{array}{l}\text { Preventing and floating } \\
\text { bridges during flood } \\
\text { season }\end{array}$ & 7.2 & 12 & - & 13.02 & 20.39 & 24.44 & 30 & \\
\hline
\end{tabular}




\section{Institutional and Financial Solutions for Inland Waterway Transport}

\subsection{Institutional Solution}

\subsubsection{Infrastructure Management}

It is necessary to increase the number and technical expertise of the VIWA staff. It is estimated that there are only more than 100 staff specializing in infrastructure management activities on national waterways $(7074 \mathrm{~km})$ or in other words, an average person $/ 70 \mathrm{~km}$ of waterways. In addition, the number of employees with professional and technical qualifications is low. Even in the context of most dredging and maintenance activities performed by contractors, this number is not sufficientand only a small fraction of the number of employees of VIWA in the field of regulatory management.

IWT industry will need more human resources (especially highly qualified engineers) if funding for maintenance and investment in infrastructure upgrading continues to increase in the near future. The research team advocates the policy of handing over daily management activities to regional offices that are more familiar with the infrastructure systems they manage and the intended use. However, large investment projects should be centrally managed as a central function, but with appropriate local field supervision. The Ministry of Transport has established Project Implementation Committees (PIUs) for investment projects funded by the World Bank. However, in principle, the project implementation committee should be under an implementing agency like VIWA rather than the line ministry in charge of policy making. VIWA needs to have the capacity and resources to carry out investment projects, provide and manage the implementation activities of the implementation board for future international financial institution loans.

E-bidding helps improve the efficiency and transparency of bidding activities. Due to the relatively small number of staff of VIWA working in the field of infrastructure management, it is important to ensure the most efficient operation possible from hiring outside contractors for waterway management and maintenance. Contractors include (but are not limited to) companies established from the previous 15 regional units of VIWA. Each region has multiple contracts, usually with a one-year term. The implementation of the electronic bidding system can help ensure fairness and transparency for these contracts, encourage more contractors to participate, increase bidding efficiency and reduce the risk of corruption.

Infrastructure maintenance function of VIWA is subject to annual performance targets through an implementation performance index. The performance indicators of VIWA are different from the "panoramic" goals mentioned in the Five-Year Plan of MOT, which only supports the monitoring of sector-wide activities and is not suitable for monitoring the performance of individual government agencies. Government agencies around the world are increasingly using performance indicators as an effective operational planning and monitoring tool. These indicators help set goals, evaluate performance and guide management decisions in the use of resources.

Performance indicators will be able to exert efficiency at the regional level, headquarters of VIWA and the Ministry of Transport. These indicators allow to manage VIWA's infrastructure in regional offices to measure inputs and outputs, helping the central management agency of VIWA. It monitors the operational efficiency of the regional management office and allows the Ministry of Transport to monitor the overall performance of VIWA in meeting the set goals. Table 9 summarizes the applicable infrastructure management performance indicators. Input index is about the performance of VIWA. The output index is about functionally efficient. The usual monitoring period for indicators is monthly and / or yearly. The indicator should be monitored for (1) each waterway section, (2) for each of the 3 waterways and (3) the entire national waterways managed by VIWA. The waterways will be geographically reasonable and can match the sections used in each maintenance contract based on performance. The Directorate of VIWA team with expertise and in-depth understanding of the Agency's operations can revise and complete this list. 
Table 9. Reference performance index for infrastructure management function of VIWA

\begin{tabular}{|c|c|c|}
\hline Type & Index & Unit \\
\hline \multirow{5}{*}{ Input factors } & Dredged volume is practicable & $\mathrm{m}^{3} /$ period \\
\hline & $\begin{array}{l}\text { River bank stabilization works have been } \\
\text { completed }\end{array}$ & $\mathrm{m} /$ period \\
\hline & Buoy signaling has been repaired / replaced & Number / period \\
\hline & Dredging costs & $\mathrm{VND} / \mathrm{m}^{3}$ \\
\hline & Dredging costs & $\mathrm{VND} / \mathrm{km}$ \\
\hline \multirow{7}{*}{ Output factors } & $\begin{array}{l}\text { The ratio of the length of the stream response } \\
\text { to classification }\end{array}$ & $\%$ of kilometer / period \\
\hline & $\begin{array}{l}\text { The number of travel days is lower than the } \\
\text { standard for section classification }\end{array}$ & Day / year \\
\hline & The ratio of signal buoys normal operation & $\%$ signal buoys / period \\
\hline & $\begin{array}{l}\text { Traffic disruption due to damaged / faulty } \\
\text { infrastructure }\end{array}$ & Interruption / period \\
\hline & $\begin{array}{l}\text { Total downtime due to infrastructure failures } \\
\text { / failures }\end{array}$ & $\begin{array}{l}\text { Number of days and\% of day } / \\
\text { period }\end{array}$ \\
\hline & $\begin{array}{l}\text { Total inactivity due to floods / high water } \\
\text { levels }\end{array}$ & $\begin{array}{l}\text { Number of days and\% of day / } \\
\text { period }\end{array}$ \\
\hline & $\begin{array}{l}\text { Total inactivity due to drought / low water } \\
\text { level }\end{array}$ & $\begin{array}{l}\text { Number of days and } \% \text { of day } / \\
\text { period }\end{array}$ \\
\hline
\end{tabular}

The Asset Management System (AMS) will improve the infrastructure management capacity of VIWA and help take advantage of the maintenance budget and invest more effectively. The asset management system includes many concepts and modules, but generally will have the following key elements: Comprehensive asset inventory; Regularly monitor the status, use and performance of the waterway network; Set priority and systematically manage maintenance tasks; Systematic investment in new construction / renovation.Asset inventory information is collected, classified and updated on an electronic database. GIS systems can locate and integrate assets in waterways and exploit satellite imagery as well as other illustrations (some systems allow continuous video tracking). The property inventory database can allow VIWA to record property characteristics, technical descriptions, conditions, maintenance history, use, and systematic performance of the property. Understanding and regularly updating the status of assets ensures better targeting for maintenance. This analysis can also indicate problems that exist in maintenance operations and measure the outcome of fixing those problems, also to consolidate the forecasting capacity to apply routine preventive maintenance procedures and to more accurately assess the budget needed for future maintenance activities. Property use data can be collected through automatic measurement or by survey, depending on the type of asset involved. Automatic river / canal condition monitoring system can provide real-time data on waterway depth and traffic channel condition. The status / inventory data in the asset management system is also the main input of the River Information Service; This shows the importance of quickly starting to build the asset management system.

For new construction projects, the ability to cope with climate change can be integrated in technical methods and design standards. Because Vietnam currently has very few large capital construction projects, it is not difficult to meet the climate change guidelines. However, in maintenance of waterway transport infrastructure, the challenge is more complex. With more than 7,000 km of national waterways, trying to adjust all routes in the waterway network to adapt to extreme climate scenarios is neither feasible nor cost-effective. Therefore, VIWAshould prioritize the level of responsiveness to this policy. At the same time, the Department should also consider doing "risk analysis" to identify which routes within the national waterway network are most at risk from climate change events with the highest probability of happening, not the most extreme. Priority can be determined for the routes most at risk by usage volume. Accordingly, VIWA can begin to develop design and performance standards related to climate change resilience in maintenance contracts,starting with high priority routes, areas that are both "at highest risk" and have "the greatest traffic volume".

The waterway information service and proactive traffic management can help VIWA to operate safer and more 
efficient waterway capacity in high-density areas. The term River Information Services (RIS) may include many different elements. The RIS concept is information services designed to enhance the safety and effectiveness of IWT by sharing information, enabling the regulator to manage the infrastructure and boat operators to optimize operations. The European Union also has the idea of harmonizing the system structure and protocols between the countries through which the main waterway runs. RIS usually includes an electronic repository and represents water assets, combined with AIS (Automatic Identification System) on board with global positioning systems and can transmit and receive data such as train format codes, type, location, speed and path and receive this information from other devices.Fast electronic "on-demand" data transfer between ship and shore authority through real-time information exchangeand voice communication can support active traffic management, advice or navigation for boats. Traffic management activities will be improved, especially on high-density waterways, near crowded ports or in docks.

\subsubsection{Regulatory Management}

Sector regulatory functions can be strengthened by both short-term and long-term actions. These include: issuing regulatory manuals, developing interactive electronic management guides; redesign the Port Authority processes and automate a number of processes; apply management performance indicators as prescribed; and assess the feasibility of the inland waterway transport enforcement system in a unified manner when the waterway police function becomes the responsibility of the Inland Waterway Administration.

VIWA should consider developing and distributing manuals (or books) to boat and port operators. The website of VIWA publishes current legal documents in a rather complicated and unfocused source. The design and drafting of the manual can make it easier for operators to understand the parts of the law that apply to them, especially for small operators and may have limited education. These documents are not legal documents and are only quoted, not replaced. In terms of presentation, the manuals can summarize legal requirements and illustrate some of the rules with compelling imagery for advising boat operators and the port of "good practice practices" such as safety anchoring practices, ways of overtaking and emergency action. Many companies in the industry or companies intending to enter the market can benefit from web-based interactive tools for reference purposes. Many small barges operators without stable Internet access will need hard copies of manuals while medium to large businessesas well as cooperatives can take advantage of modern web-based IT tools to access regulatory information. Building this online tool requires resources, commitment and thorough preparation. By combining web-based content with interactive tools and "deals" features like an online ship registration form or an operator license, the website of the Inland Waterway Administration may include a full-featured electronic regulation handbook for many stakeholders. The components of this tool can be added to the output for a smartphone or tablet application for offline use when out of range.

VIWA should conduct a detailed inspection of Port Authority practices and procedures to understand the possibility of simplification and automation. A new approach that can be considered is the "trusted business" program. Domestic transport operators with a history of good compliance may be exempted from certain inspection requirements, self-submissions, and bulk charges to port authorities. Similarly, larger inland port companies may be assigned a number of ship inspection functions that normally fall within the port authority's responsibility and submit necessary documentation and fees to VIWA.If large companies and cooperatives can be certified into the 'trusted businesses' program, with all electronic and paper records and payments, VIWA can focus resources more effectively on ensuring compliance of operators with 'higher risk'. The process of process redesign may result in a design model from the outset to achieve the management goals of VIWA. Potential benefits include improved work efficiency of industry regulators, improved quality management services for the inland waterway sector, reduce unnecessary legal burden and prevent the risk of corruption. The success of this process can partly depend on the rational exploitation of technology. The productivity and consistency of performing port authority's regular functions can be improved by automating electronic notification of port requirements and authorizations, check ship and crew records, record shipping information and pay port fees electronically.

It is necessary to monitor the effectiveness of the sector regulatory management of VIWA similar to the monitoring of infrastructure management performance, but with a different set of indicators. The regulatory regulatory function of VIWA establishes an annual operational goal for regulatory and outcome activities. These indicators can help VIWA better supervise the work of the port authorities and help the Ministry of Transport to monitor the annual performance of VIWA in achieving the set goals. Table 10 illustrates the performance of sector regulatory management based on the current functions of the port authority. However, it would be better to first conduct a comprehensive study to redesign the functions as this could improve performance indicators of port authorities. 
Table 10. Performance indicators for port authorities of VIWA

\begin{tabular}{|c|c|}
\hline Index & Unit \\
\hline Ports should be fully inspected for safety & Quantity / period \\
\hline Official notice of port safety issues & Quantity and \% / period \\
\hline Port safety notices are checked and corrected & Quantity and \% / period \\
\hline Port safety notices are checked and corrected & Quantity / period \\
\hline River crossings need full safety inspection & Quantity and \% / period \\
\hline Official notice on safety issues of cross-river wharves & Quantity and \% / period \\
\hline Issuing permit for vessels entering and leaving ports and cross river & Quantity / period \\
\hline Permission to refuse vessels entering and leaving ports and cross river & Quantity and \%/ period \\
\hline Analysis of reasons for refusal to permit port entry and exit & $\%$ by reason / period \\
\hline The number of loading and unloading activities is monitored & Quantity / period \\
\hline $\begin{array}{l}\text { The number of loading and unloading activities on the ship halted for more } \\
\text { than } 1 \text { hour due to violations of safety regulations }\end{array}$ & Quantity and \% / period \\
\hline $\begin{array}{c}\text { Analysis of reasons for temporary suspension of loading and unloading } \\
\text { activities }\end{array}$ & $\%$ by reason / period \\
\hline Number of search and rescue operations organized & Quantity / period \\
\hline Number of boats / individuals rescued & $\begin{array}{l}\text { Number of boats and } \\
\text { individuals / stage }\end{array}$ \\
\hline Number of official accident investigations initiated & Quantity / period \\
\hline The number of official accident investigation has concluded & Quantity / period \\
\hline Transactions paid port fee & $\begin{array}{l}\text { Number of boats paying fees / } \\
\text { period }\end{array}$ \\
\hline Amount of port fee collected & VND collected / period \\
\hline The sum of the port fee collection is in cash & Amount (VND) and\% / period \\
\hline
\end{tabular}

In the long term, the Government of Vietnam may need to consider the feasibility and potential benefits of the transfer of monitoring and control functions and enforce the waterway law for the Ministry of Transport (through VIWA). Under the supervision of VIWA, the enforcement of water law compliance will also include a range of traffic management and control functions.VIWA currently has no duty, equipment or resources to patrol waterways, enforce traffic rules, manage traffic problems or respond to emergencies, but as an emergency. As a national "water infrastructure management agency," VIWA may have the most direct interest in the effectiveness of these activities. Besides, it is also necessary to set up the problem of improving safety of the industry and accident statistics currently undertaken by the Waterway Traffic Police. Although the Waterway Traffic Police collect accident statistics, VIWAis the unit with the greatest need to use these figures to complete both the tasks of infrastructure management and regulatory management.Current accident statistics tend to look for the cause of an accident due to human error or human negligence(operators run recklessly, go in the wrong lane or lane, operate unsafe equipment, overloaded boats and boats without appropriate permits). Although these situations do not justify risky train behaviors, poor quality infrastructure can contribute to train faults or undisciplined behavior. While information about the "cause of the mistake" may help the regulatory function of VIWA, it is equally important,"real-life" information will help infrastructure managers identify potential problems and take preventive action. For that reason, both types of accident statistics need to be collected and published.

\subsubsection{Integrated Management}

The main measures proposed at IW's integrated management level are related to the 2018 Master Plan to reach businesses and the community. In addition to its technical role as an agency in charge of infrastructure and regulatory regulation,VIWA needs to strengthen its promotion role in the industry, interact with national and international stakeholders to promote private sector investment and encourage IWT development.However, any communication strategy needs a two-way process. It is important not only that VIWA informs the industry about the current activities of the Department, but also to ensure the opposite direction, that is, VIWA is aware of current industry 
activities. The task is not only to provide information to the community, but also to demonstrate responsibility to the community about the quality and efficiency of the VIWA's work. The two main measures proposed are in charge of market supervision and implementation of community accountability program.

VIWA has the motivation and mission to monitor trends and needs in the IWT industry. The nature of IWT industry is very diverse and dispersed by geographic area, so it is difficult to give general information about the industry. VIWA should consider short-term strengthening the capacity to monitor and evaluate the development trends of IWT market and market as a basis for promoting and supporting the industry in a longer and more positive way.Market watchdogs provide regular analysis reports covering four areas:analysis of IWT needs; analysis of services provided by the inland waterway market; overview of traffic conditions on inland waterways of Europe; and microeconomic analysis of the industry. IWT industry should also have promotion activities aimed at new users because this is still a narrow market method.The idea of this activity is to create a list of companies in your industry of interest, select a short list that includes the most potential customers,include them in programs to approach and support the use of IWT services by exploiting customers and businesses and infrastructure managers together to provide long-term IWT services to meet market demand.VIWA should also be more proactive in community accountability and industry promotion. The annual report on the inland waterway sector requires approval from the Ministry of Transport and consists of three parts: an overview of the inland waterway system trend and the development profile of the year; operation and performance of VIWA in infrastructure management and regulatory management; and VIWA's annual financial statements.

\subsection{Financing Solution}

\subsubsection{Establish a Waterway Maintenance Fund}

The Ministry of Transport / VIWA may study and establish the Waterway Maintenance Fund (WMF) based on the experience of the Road Maintenance Fund. Setting up a specialized fund will not guarantee an increase in invested capital. However, this activity helps the industry to focus on longer-term investment needs and resources and to ensure there is more stable investment capital than the annual budget processes. The main funding source of this Fund may be the state budget, fees collected from water transport and may include tax subsidies on road vehicles as experienced by some countries. This fund will significantly improve VIWA's capacity to ensure smooth navigation.

The Ministry of Transport should consider adjusting the allocation of investment capital in the industry so that VIWA is allocated more capital, commensurate with its contribution to the total volume of domestic freight. This imbalance takes place even though the costs incurred by third parties for transportation by road (financial, economic and environmental costs) are much higher. The same situation exists in other countries, often due to "unattended" water transport,need for infrastructure development has not been given much attention, while road management agencies are often more large-scale and better-resourced, enabling the sector to allocate more budgets and consume more state investment.Therefore, the allocation of budget for IWT and roads is currently prioritizing the mode of transportation with the highest negative impact on the community. Such budget allocations are inappropriate. The Prime Minister's Decision No. 47/2015 increases the allocation budget for IWT to 2020.As a result, VIWA's budget in recent years has increased significantly. However, Vietnam needs to implement a unified, continuous strategy towards increasing long-term investment capital after 2020.Due to the fact that the Ministry of Finance is less likely to allocate more budget to the transport sector, to increase the investment capital for IWT. This sector needs to reallocate from the cost of the road transport sector (including investment budget and recurrent expenditure).

Port authorities at VIWA now collect fees and charges for the use of inland ports and wharves. At the moment, there are no fees or other charges from transport users using the water transport network, if implemented, it can help VIWA to fulfill its responsibilities for infrastructure management. There are also a number of reasons for regulating the Water Maintenance Fund to collect an annual operating license fee for inland ports and wharves. Deploying the use of inland ports and wharves is bringing commercial benefits to the operators of these ports.In order for VIWA to receive these benefits directly, the Ministry of Finance needs to revise the regulations on the rate of charges that must be paid to the budget and withheld, allowing VIWA to retain some of the fees collected. This figure should probably account for $90 \%$ of the charge on tonnage.

Vietnam may also consider transferring a portion of the road traffic tax to the Waterway Maintenance Fund. Funding may include a certain percentage of road vehicle taxes or fuel taxes. This "support" measure for the IWT sector can help overcome the road transport situation, although incurring more costs to the third party (such as pollution costs, carbon emissions and accidents) compared to IWT but have not yet offset these costs. Some countries such as China, Germany and France use taxes and fees collected by road users to finance some of the other modes of transport. 


\subsubsection{Capital Investment in Infrastructure Construction}

VIWA called for additional investment not feasible. Some organizations that manage public transport infrastructure can mobilize off-budget financing from foreign investors. However, this can only be done if these organizations have sufficient funds to repay the debt and provide a form of enforceable guarantee for repayment. VIWA cannot do so because it is not able to borrow as an independent organization with negative income streams and has almost no collateral (VIWA does not own the right to develop facilities and services on either side of the waterway). This is the reality of the world's oldest and most crowded inland waterway traffic management systems. In the three cases where we conducted a case study, the tax revenue collected from road users was only enough to cover part of the operating costs and maintenance of waterways, seldom to cover the cost of construction and improvement of these infrastructures.

ODA is still an attractive source of funding for infrastructure construction, although it requires the state to provide funds to repay debts. With government approval, the Ministry of Finance / VIWA can, in principle, access relatively attractive loans from international development banks such as the World Bank, Asian Development Bank, Asian Infrastructure Development Investment Bank. These loans are for specific projects that meet the loan, financial and other requirements of each bank.Currently, the main source of debt repayment is from the state budget, that is, from the taxpayer's pocket. ODA is unlikely to be a sustainable source of capital to fund long-term capital investment projects as Vietnam continues to maintain economic growth momentum. The Ministry of Finance may reallocate part of its budget for road infrastructure construction to IWT infrastructure construction investment projects to cover project operation costs. The transfer of only a modest budget for the development of road transport infrastructure (about 3-5\%) also helps to significantly increase the funding for the waterway transport sector, while only little impact on the road network development progress.

With the desire to encourage the private sector to invest in government transport infrastructureand VIWA has compiled a list of IWT development projects that have the potential to follow the Public - Private Partnership model on its website as well as in investment promotion and promotional materials. In principle, the private sector can contribute their skills, experience and valuable resources to the project. Private investment can be a practical solution for projects developing ports and wharves with good traffic. Waterway development projects related to the construction of roads and operating structures are more difficult. The Government of Vietnam should apply the principle that VIWA or the Ministry of Finance leases or concessions to competing private businesses to invest and upgrade and maintenance of parts of transport management infrastructure for a certain number of years in return for a toll. However, experience in the world shows that without financial support from the government, the private sector is less willing to accept the technical risks of waterway transport projects and the risk of revenue from commercial activities. That means the government should take market risks when trying to collect fees from users and the government uses this revenue to partially offset payments for services and infrastructure provided by private enterprises. Therefore, the Government needs to identify and design PPP projects with guarantees or commitments to be able to successfully attract private investment. It is not possible to successfully implement Public - Private Partnership projects using only the "arithmetic" process.That means public-private partnership projects and similar projects involving the private sector are not the end result of the calculation of all construction investment projects that the Government has determined to subtract projects that are self-financing. The rest are Public - Private Partnership projects (or other mechanisms of public and private resources).

\subsubsection{Investment in Construction of Port and Wharf Infrastructures}

These ports and wharves are owned by private enterprises, which are responsible for investing in these infrastructure. The team does not support diverting scarce financial resources from VIWA's investment items in national water transport infrastructure. In contrast, ports and wharves are more suitable for private investment. However, we believe that provincial / municipal governments may be more proactive in participating by adopting the portholder model, shown below.

Provincial and municipal governments are legally responsible for implementing the national goals for IWT development. These agencies also have local benefits in terms of traffic in the form of economic benefits brought about by the operation of ports and wharves. The successful and popular model of port and wharf organization in the world is the "port owner" model, in which state agencies (usually subordinate to local governments) own and invest in basic infrastructure such as wharves, piers, land areas, road connections,... while the private sector invests and operates transportation services such as ship control, cargo handling, warehousing.

The Government of Vietnam may consider adopting this model at 2-3 main inland ports that need the most investment. The provincial government will agree to co-sponsor or partially fund the investments needed to build 
port infrastructure and connect roads and provide expanded land funds as needed. However, these investments depend on the commitment of the private unit operating the port to adequately invest in such items as mechanized loading and unloading of goods, warehousing, storage or not. This approach helps the provincial and municipal governments become more involved in the activities of the ports and wharves they are responsible for managing. In addition, the harmonious combination of benefits of local authorities and private operators also ensures that this model works effectively and more sustainable than just exempting land rental or interest rate subsidies from private operators.

\subsubsection{Improve the Process of Capital Preparation and Project Implementation}

Adequate and appropriate project preparation is important for the project's feasibility assessment in order to identify appropriate funding sources and investment methods. This is certainly true for ODA-funded projects, (potentially) funded projectsand especially projects that raise private capital in the form of PPP, BOT, BT cooperation or other public-private agreements. Whether public or private, successful implementation of these projects often requires the steps shown in Figure 1.

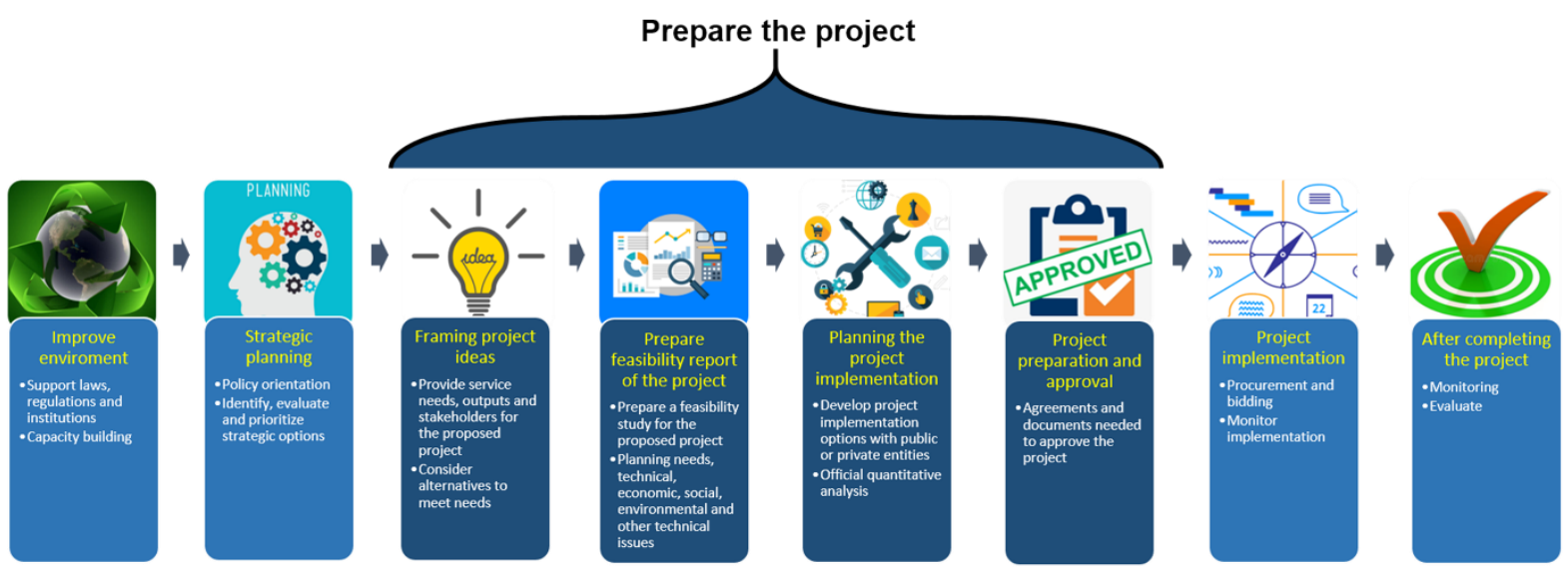

Figure 1. Proposed project preparation steps

VIWA, together with the Ministry of Finance, the Ministry of Transport and other relevant agencies need to cooperate to build and enhance the knowledge and experience to carry out these steps and research. In addition to building trust among potential private investors, these studies will provide VIWA and the Ministry of Transport with important reasons to increase capital allocation from the state budget.

\section{Conclusion}

Immediately after joining the international economic community in the late 1980s, Vietnam considered the development of inland waterway transportation as one of the top priorities to promote economic growth. Despite the limited budget, Vietnam has made great strides in developing inland waterway transportation by effectively exploiting the natural conditions from the river and canal system. Notably, IWT's traffic volume has increased by $47 \%$ between 2010 and 2016. However, relying only on natural conditions will lose the competitive advantage of the industry.

The paper emphasized the need for reform measures, with the core being an institutional framework such as separate infrastructure management and sector regulatory functions. Highlight the role of improving the enabling environment by issuing a handbook to disseminate industry laws and regulations to make them more accessible to users. Furthermore, it was confirmed that the partial transfer of funding for the road sector to inland waterwaysand building transparent, effective roadmaps that can encourage the private sector to participate in providing infrastructure as well as operating and maintenance services in this area.

With a long-term vision, investment priorities and political determination, the reform program may help the government address many of the constraints that limit the development potential of inland waterway transport in Vietnam. Vietnam's development process will be supported more smoothly and reliably when goods can flow safely 
and effectively on the wide inland waterway network. Increasing investment and effective management of the infrastructure network will also accelerate the trend of container shipping by new industries and reduce logistics costs, an area where Vietnam is in need of improvement compared to competitors such as China, Malaysia and Thailand.Continuing to improve the network infrastructure network will also improve and promote the environmental advantages of waterway transport with greenhouse gas emissions 2 - 3 times lower than road transport. The role of IWT industry in the development of the country is more important than ever.

\section{References}

Banomyong, R., Thai, V. V., \& Yuen, K. F. (2015). Assessing the national logistics system of Vietnam. The Asian Journal of Shipping and Logistics, 31(1), 21-58.

Chandra, Y. R. V. S., Shiva Harun, M., \& Reshma, T. (2017). Intelligent transport system. International Journal of Civil Engineering and Technology. https://doi.org/10.1016/b978-075065865-2/50014-6

Chen, C., Tabssum, N., \& Nguyen, H. P. (2019). Study on Ancient Chu Town Urban Green Space Evolution and Ecological and Environmental Benefits. Nature Environment and Pollution Technology, 18(5), 1733-1738.

Dang, G., \& Pheng, L. S. (2015). Vietnam-Economic, Trade and Infrastructure Overview. In Infrastructure Investments in Developing Economies (pp. 81-133). Springer.

Dang, N. B., Momtaz, S., Zimmerman, K., \& Hong Nhung, P. T. (2017). Effectiveness of formal institutions in managing marine fisheries for sustainable fisheries development: A case study of a coastal commune in Vietnam. Ocean and Coastal Management. https://doi.org/10.1016/j.ocecoaman.2016.12.021

Dang, V. L., \& Yeo, G. T. (2018). Weighing the Key Factors to Improve Vietnam's Logistics System. The Asian Journal of Shipping and Logistics, 34(4), 308-316.

Hoang, A. T., \& Chau, M. Q. (2018). A mini review of using oleophilic skimmers for oil spill recovery. Journal of Mechanical Engineering Research \& Developments, 41(2), 92-96.

Hoang, A. T., \& Pham, V. V. (2018). A review on fuels used for marine diesel engines. Journal of Mechanical Engineering Research \& Developments, 41(4), 22-32.

Hoang Phuong, N., Minh Tuan, N., \& Minh Tuan, P. (2019). Logistics Revolution for e-commerce in Vietnam : A Brief Review. International Journal of E-Navigation and Maritime Economy, 13, 50-62.

Howe, C. W., Carroll, J. L., Hurter Jr, A. P., Leininger, W. J., Ramsey, S. G., Schwartz, N. L., ... Steinberg, R. M. (2016). Inland waterway transportation: studies in public and private management and investment decisions. Routledge.

Kim Dung, N., Bush, S. R., \& Mol, A. P. J. (2017). The Vietnamese legal and policy framework for co-management in special-use forests. Forests. https://doi.org/10.3390/f8070262

Konings, R., \& Wiegmans, B. (2016). Inland waterway transport: An overview. In Inland Waterway Transport (pp. 17-33). Routledge.

Lebovics, M., Hermes, N., \& Hudon, M. (2016). Are financial and social efficiency mutually exclusive? A case study of Vietnamese microfinance institutions. Annals of Public and Cooperative Economics, 87(1), 55-77.

Mubarik, M., \& Zuraidah, R. (2019). Triad of Big Data Supply Chain Analytics, Supply Chain Integration and Supply Chain Performance: Evidences from Oil and Gas Sector. Humanities and Social Sciences Letters, 7(4), 209-224.

National Assembly, V. Law on inland waterway transport (2014).

Nguyen, H. P. (2019). Blockchain - an indispensable development trend of logistics industry in Vietnam : Current situation and recommended solutions. International Journal of E-Navigation of Maritime Economy, 13, 14-22.

Nguyen, H. P. (2020a). Human Resource Management of Logistics in Vietnam: Status and Policy Solutions. International Journal of Innovation, Creativity Anh Change, 11, 68-74.

Nguyen, H. P. (2020b). Sustainable Development of Logistics in Vietnam in the Period 2020-2025. International Journal of Innovation, Creativity anh Change, 11, 230-239.

Nguyen, H. P., \& Pham, V. T. (2020). Toward The Green Logistics By Developing Sustainable Transportation: A Case Study From Vietnam. GIS Business, 15(1), 127-141.

Nguyen, X. P. (2019). The bus transportation issue and people satisfaction with public transport in Ho Chi Minh city. 
Journal of Mechanical Engineering Research and Developments. https://doi.org/10.26480/jmerd.01.2019.10.16

Nguyen, X. P., \& Pham Nguyen, D. K. (2019). Experimental Research on the Impact of Anchor-Cable Tensions in Mooring Ship at Vung Tau Anchorage Area. International Journal on Advanced Science, Engineering and Information Technology, 9(6), 1892-1899.

Pham, T. Y., \& Yeo, G.-T. (2019). Evaluation of Transshipment Container Terminals' Service Quality in Vietnam: From the Shipping Companies' Perspective. Sustainability, 11(5), 1503.

Pham, V. T. (2019). The expanding tendency of logistics major in the 4.0 industrial revolution: A case study in Vietnam. International Journal of E-Navigation of Maritime Economy, 11, 1-13.

Pham, V. V., \& Hoang, A. T. (2019). Technological perspective for reducing emissions from marine engines. International Journal on Advanced Science, Engineering and Information Technology, 9(6), 1989-2000.

Phuong, N. H. (2019). What solutions should be applied to improve the efficiency in the management for port system in Ho Chi Minh City?. International Journal of Innovation, Creativity and Change, 5, 1747-1769.

Raschky, P., \& Chantarat, S. (2020). Natural Disaster Risk Financing and Transfer in ASEAN Countries. In Oxford Research Encyclopedia of Natural Hazard Science.

Shultz, C. J., \& Peterson, M. (2019). A Macromarketing view of sustainable development in Vietnam. Environmental Management, 63(4), 507-519.

Smajgl, A., Toan, T. Q., Nhan, D. K., Ward, J., Trung, N. H., Tri, L. Q., ... Vu, P. T. (2015). Responding to rising sea levels in the Mekong Delta. Nature Climate Change. https://doi.org/10.1038/nclimate2469

To, N. T., \& Kato, T. (2018). Characteristics and development of policy and institutional structures of emergency response in Vietnam. International Journal of Disaster Risk Reduction. https://doi.org/10.1016/j.ijdrr.2018.07.016

Utomo, D. M., \& Mateo-Babiano, I. (2015). Exploring indigeneity of inland waterway transport (IWT) in Asia: case studies of Thailand, Vietnam, the Philippines, and Indonesia. Journal of the Eastern Asia Society for Transportation Studies, 11, 2316-2332.

Vietnam's Transport Sector. (2017). Vietnam's Transport Sector. Vietnam National Transport Strategy Study (VITRANSS).

VIWA. (2020a). Functions and Responsibilites. Retrieved from http://en.viwa.gov.vn/functions-and-responsibilites

VIWA. (2020b). Inland Waterway Master plans: Panning of Waterway Main Routes and Ports in the North up to 2020 - 2030. Retrieved from http://en.viwa.gov.vn/inland-waterway-master-plans

Vu, K., \& Hartley, K. (2018). Promoting smart cities in developing countries: Policy insights from Vietnam. Telecommunications Policy. https://doi.org/10.1016/j.telpol.2017.10.005

Weber, O., \& Feltmate, B. (2016). Sustainable banking: Managing the social and environmental impact of financial institutions. University of Toronto Press.

Wiegmans, B., \& Konings, R. (2015). Intermodal inland waterway transport: Modelling conditions influencing its cost competitiveness. The Asian Journal of Shipping and Logistics, 31(2), 273-294.

Wiegmans, B., \& Konings, R. (2016). Inland Waterway Transport: Challenges and Prospects. Routledge. 